\title{
РЕГИОНАЛЬНЫЕ ОСОБЕННОСТИ ЭКОЛОГО-ЭКОНОМИЧЕСКОГО РАЗВИТИЯ АГРАРНОГО СЕКТОРА ЭКОНОМИКИ
}

\author{
В.И. Батыров ${ }^{1}$, В.С. Курасов ${ }^{2}$, С.И. Камбулов ${ }^{3}$ \\ ${ }^{1}$ Кабардино-Балкарский государственный аграрный университет \\ им. В.М. Кокова \\ Российская Федерация, 360031, КБР, г. Нальчик, пр. им. Ленина, $1^{\text {в }}$ \\ E-mail: batyrov.53@mail.ru \\ ${ }^{2}$ Кубанский государственный аграрный университет им. И.Т. Трубилина \\ Российская Федерация, 350044, г. Краснодар, ул. Калинина, 13 \\ ${ }^{3}$ Аграрный научный центр «Донской» \\ Российская Федерация, 347740, г. Зерноград, ул. Научный городок, д. 3
}

Данная статья посвящена исследованию региональных особенностей экологоэкономического развития аграрного сектора экономики. Показано, что существующие основы развития отечественного аграрного сектора во многих случаях ограничены, в определенной степени устаревшие, не соответствуют современному методологическом трактовке их сущности и экономической целесообразности, недостаточны с точки зрения методических приемов в практике ведения системы аграрного хозяйствования, не всегда учитывают прогрессивный опыт экономически развитых стран, в частности европейский как наиболее приемлемый для отечественной аграрной культуры. Такие подходы требуют расширенной научной дискуссии, широкого обсуждения с целью повышения действенности научно-практических наработок в данной сфере.

Ключевые слова: аграрный сектор, рыночные условия, эффективность, устойчивость, воспроизводство.

Аграрный сектор как весомая в экономическом, экологическом и социальном смысле составляющая в современных рыночных условиях играл и продолжает играть значительную роль в развитии национальной экономики. Он выполняет ряд важных макро- и микроэкономических функций, в частности - обеспечение продовольственной безопасности страны, формирования значительных объемов экспортных поступлений, обеспечения перерабатывающих отраслей промышленности сырьем, трудоустройство жителей сельской местности и тому подобное. На сегодня положительно меняется структура аграрного производства - ускоренно растет доля сельскохозяйственных предприятий, опережая прирост основных параметров хозяйств населения [1-3].

Вместе с положительными составляющими, отечественный аграрный сектор нуждается в кардинальных изменениях в аспекте управления основными процессами, детерминирующих развитие, формулировка прогрессивных целей и обновления мотиваций аграрного хозяйствования, принятия эффективных решений, в частности с учетом международного опыта.

Доминирование аграрной среды, как типичной для экономики России, является традиционным и останется таковым на ближайшую перспективу. Указанное объясняется длительной в историческом ракурсе культурой ведения сельского хозяйства в России, благоприятными природно-климатическими условиями для подъема системы аграрного хозяйствования по различным отраслям, достаточно высокой долей населения, задействованной в сфере аграрных отношений, значительными предпринимательскими инициативами, связанными с аграрным производством, торговлей сельскохозяйственным сырьем, полуфабрикатами, готовыми аграрными продуктами, развитием сельских территорий на базе как производственных, так и дополняющих компонентов.

Указанные составляющие определяют типичную ситуацию в аграрном среде России, которая может быть использована как базовая к воспроизводству на новом 
рыночном уровне - структурном, функциональном, коммуникативном. Существующие основы развития отечественного аграрного сектора во многих случаях ограничены, в определенной степени устаревшие, не соответствуют современному методологическом трактовке их сущности и экономической целесообразности, недостаточны с точки зрения методических приемов в практике ведения системы аграрного хозяйствования, не всегда учитывают прогрессивный опыт экономически развитых стран, в частности европейский как наиболее приемлемый для отечественной аграрной культуры. Такие подходы требуют расширенной научной дискуссии, широкого обсуждения с целью повышения действенности научно-практических наработок в данной сфере.

Отечественный аграрный сектор по структуре и функционированием достаточно сложным и коммуникативно насыщенным, что позволяет, с одной стороны, обеспечивать процессы сельскохозяйственного производства в форме земледелия, растениеводства, животноводства и других близких отраслей, в частности лесоводства, с другой воспроизводить аграрные отношения на уровне аграрного производства, разнонаправленных предпринимательских инициатив, всесторонне развивать аграрную сообщество, формировать действенную и перспективную аграрную политику, обогащая ее новыми экологически и социально ориентированными проектами, инновационными стратегиями развития и практически реализовывать их на уровне отдельных субъектов хозяйствования, создавая своеобразный «микроклимат» в аграрном среде.

Аграрное производство является экономической основой сельского хозяйства, гарантирует необходимый уровень продовольственной безопасности страны, создает мощную сырьевую базу для развития перерабатывающей пищевой промышленности, отдельных отраслей легкой, химической, деревообрабатывающей промышленности, альтернативной энергетики. Развитию аграрного сектора способствуют близость основных рынков сбыта, транспортная инфраструктура (железная дорога, дороги, порты), постоянный рост мирового спроса на продовольственные продукты и альтернативную энергетику, а также наличие сравнительно дешевых трудовых ресурсов.

С экологических позиций аграрное производство находится под влиянием природно-климатических факторов и непосредственно задействовано в комплексной агроэкологической системе [4-5]. Поэтому, на первый взгляд, может показаться неподходящим, что аграрный сектор, будучи почти элементом природы, вызывает в России треть всех загрязняющих выбросов и некоторые другие неблагоприятные экологические действия. Последствиями агроэкологической несоответствия является низкая эффективность процессов в сельском хозяйстве России, как базовых производственных, финансово-экономических, предпринимательских и т.д., так и сопровождающих, связанных с недостаточным экологическим развитием сельских территорий. Это, а также множество других агроэкологических составляющих (которые будут рассмотрены в дальнейшем) определяют высокую актуальность вопросов экологизации аграрного производства и необходимость повышения эффективности функционирования отечественных аграрных предприятий как основных субъектов аграрного хозяйствования.

Среди экономических причин значительного уровня экологических рисков в аграрном секторе национальной экономики стоит отметить такие, как:

- недостаточные финансовые возможности отечественных аграрных предприятий, в частности средних и малых, для повышения уровня экологической безопасности производства;

- ненадлежащее восприятия значимости отечественными аграриями экологической составляющей в сельскохозяйственном производстве, чему способствует, в частности значительная доля хозяйств населения в производстве валовой продукции сельского хозяйства, которые, как правило, не акцентируют достаточного внимания на вопросах экологии, а преимущественно «концентрированные» на подсобном производстве как форме экономического выживания; 
- ограниченная экономическая мотивация (как на общегосударственном, так и на региональном уровне) в экологически ориентированного сельскохозяйственного развития, коррелирует с предыдущими положения и связана с возникновением отдельных негативных агроэкологических процессов, в частности экологических нарушений в практике хозяйствования, сопровождается экологическими дисбалансами разных уровней сложности и т.п.

Такая ситуация определяет угрожающее влияние аграрного сектора национальной экономики на экологическую ситуацию в целом. Стоит отметить, что общественный интерес к экологическим проблемам, и не только аграрного сектора в целом снизился. Например, экологические специальности еще лет 5-10 назад были популярным направлением в учреждениях высшего образования, однако данная профессия в основном осталась практически не реализованным.

Имеющиеся сдерживающие факторы и по социальной составляющей, в частности уровень оплаты труда в аграрном секторе отстает от среднероссийского. И хотя этот разрыв и сокращается в последние годы, заработная плата в сельском хозяйстве России остается одной из самых низких среди видов экономической деятельности. Другой пример: если ранее аграрные предприятия как системообразующие элементы жизни села направляли достаточно весомый объем средств на его социальное благоустройство, то сейчас эта практика остается в далеком прошлом.

Характерным для отечественного аграрного производства из указанных позиций является структурное расслоение. Так, на сегодняшний день можно выделить три основные группы сельхозтоваропроизводителей:

1) крупные предприятия (образца агрохолдингов)

2) средние и малые предприятия, фермерские хозяйства;

3) хозяйства населения.

Такое деление является определяющим с точки зрения неодинакового уровня финансово-экономических доходов и разного влияния на экологическую и социальную ситуацию на селе как текущую, так и на отдаленную во времени.

Указанные и многие другие факты и факторов обусловливают несбалансированное развитие отечественного аграрного производства, предпринимательской деятельности в сельской местности, аграрных отношений между членами общества, хозяйствами по поводу создания, обмена, распределения и потребления совокупного аграрного продукта. Решение существующих проблем считаем возможным осуществить на основе концепции устойчивого развития аграрного сектора национальной экономики как современной методологической базы, отражается в соответствующих научных наработках отечественных исследователей и перспективным курсом аграрной политики России.

\section{Литература}

1.Апажев, А.К. Феномен устойчивости социо-эколого-экономического развития и саморазвития аграрно-рекреационных территорий [Текст] / А.К. Апажев, А.А. Гварамия, М.А. Маржохова // Сибирская финансовая школа.- 2015.- № 5 (112).- С. 22-26.

2.Апажев, А.К., Маржохова М.А., Халишхова Л.З. Феномен устойчивости экономико-экологического развития аграрных территорий [Текст] / А.К. Апажев, М.А. Маржохова, Л.3. Халишхова.- Нальчик, 2015.

3.Апажев, А.К. Устойчивость развития регионов в условиях пространственноэкономических трансформаций [Текст] / А.К. Апажев // В сборнике: Устойчивость развития территориальных экономических систем: глобальные тенденции и концепции модернизации. сборник научных трудов по итогам международной научно-практической конференции памяти профессора Б.Х. Жерукова. 2016. С. 10-13.

4.Kyul, E.V. Influence of anthropogenic activity on transformation of landscapes by natural hazards [Текст] / E.V. Kyul, A.K. Apazhev, A.B. Kudzaev, N.A. Borisova // Indian Journal of Ecology.- 2017.- T. 44.- № 2.- C. 239-243 
5.Апажев, А.К. Факторы продовольственной безопасности в условиях новой парадигмы сельского развития [Текст] / А.К. Апажев, С.М. Пшихачев // В сборнике: Продовольственная безопасность и устойчивое сельское развитие: глобальные, национальные и региональные аспекты. Материалы международной научно-практической конференции памяти профессора Б.Х. Жерукова. 2014. С. 3-17.

6.Хажметова, А.Л. Технологическое и техническое обеспечение повышения эффективности интенсивного горного и предгорного садоводства [Текст] / А.Л. Хажметова, А.К. Апажев, Ю.А. Шекихачев, Л.М. Хажметов, А.Г. Фиапшев // Техника и оборудование для села.- 2019.- № 6 (264).- С. 23-28. 